\title{
PENINGKATAN KOMPETENSI GURU BIDANG KEAHLIAN BISNIS MANAJEMEN MELALUI PENELITIAN TINDAKAN KELAS
}

\author{
Oleh: \\ Raya Sulistyowati', Siti Sri Wulandari², Bambang Suratman ${ }^{3}$, Harti $^{4}$ \\ 1,2,3,4 Universitas Negeri Surabaya \\ ${ }^{1}$ rayasulistyowati@unesa.ac.id
}

\begin{abstract}
Abstrak
Tujuan kegiatan ini adalah untuk memenuhi kebutuhan guru dalam meningkatkan kompetensi guru pada bidang keahlian bisnis manajemen guru-guru di SMKN 1 dan SMK Ketintang Surabaya. Alasan melakukan pelatihan penelitian tindakan kelas ini (1) untuk membuat guru menjadi peka dan tanggap akan dinamika pembelajaran di kelasnya. (2) meningkatkan kinerja guru sehingga menjadi professional.(3) guru memperbaiki proses pembelajaran melalui suatu pengkajian yang terdalam terhadap apa yang terjadi di kelasnya. (4) penelitian tindakan kelas tidak mengganggu tugas pokok seorang guru karena guru tidak perlu meninggalkan kelasnya. Hasil kegiatan tersebut berupa artikel karya ilmiah hasil penelitian tindakan kelas yang digunakan oleh guru sebagai bahan untuk peningkatan proses dan hasil belajar siswa di kelas. Diharapkan melalui pelatihan pembuatan penelitian tindakan kelas dan pendampingan penulisan naskah artikel hasil penelitian tindakan kelas. Dan pada akhirnya guru-guru SMKN 1 Surabaya dan SMK Ketintang Surabaya bidang Bisnis Manajemen dapat meningkatkan publikasi ilmiah serta dapat meningkatkan tunjangan fungsional dan angka kredit guru dalam mengembangkan karier guru.
\end{abstract}

Kata Kunci: Kompetensi Guru, Bisnis Manajemen, Penelitian Tindakan Kelas

\begin{abstract}
the purpose of this activity is to meet the needs of teachers in improving teacher competence in the field of business management expertise of teachers in SMKN 1 and SMK Ketintang Surabaya. The reason for doing this classroom action research training (1) to make teachers sensitive and responsive to the dynamics of learning in its class. (2) Improving teachers' performance to become professionals (3) teachers improves the learning process through an in-depth assessment of what is happening in their classroom. (4) classroom action research does not interfere with a teacher's main task because the teacher does not need to leave the class. The results of these activities in the form of articles of scientific work of classroom action research used by teachers as material for improving the process and the results of student learning in the classroom. It is expected that through the classroom action research training and the accompaniment of the script writing of the classroom action research results. And ultimately teachers SMKN Surabaya and SMK Ketintang Surabaya Business Management can improve scientific publications and can increase functional allowance and teacher credit numbers in developing teacher careers.
\end{abstract}

Keywords: Teacher Competence, Business Management, Classroom Action Research

\section{PENDAHULUAN}

Sekolah Menengah Kejuruan Negeri 1 Surabaya dan Sekolah Menengah Kejuruan Ketintang Surabaya merupakan lembaga yang menghasilkan tenaga kerja di bidang manajemen bisnis, sehingga proses pembelajaran yang dilakukan berorientasi pada pembentukan kompetensi yang sesuai dengan karakteristik pekerjaan bidang masing- masing. Proses pembelajaran sebagai suatu aktivitas untuk meningkatkan pengetahuan, keterampilan dan sikap siswa tersebut berkaitan langsung dengan aktivitas guru, baik di dalam maupun di luar kegiatan pembelajaran. Sebagai suatu sistem kegiatan, proses pembelajaran selalu melibatkan guru di dalamnya. Keterlibatan guru tersebut mulai dari pemilihan dan pengurutan materi pembelajaran, penerapan dan penggunaan 
metode pembelajaran, penyampaian materi pembelajaran, pembimbingan belajar, sampai pada kegiatan mengevaluasi hasil belajar.

Guru merupakan salah satu kunci utama penentu keberhasilan pendidikan, termasuk semua proses di dalamnya. Guru yang berkualitas akan dapat mengajar dengan baik, merencanakan dan menggunakan strategi pembelajaran yang tepat, sehingga siswa akan terfasilitasi untuk belajar dengan mudah dan efektif, yang akhirnya dapat meningkatkan prestasi belajar siswa. Guru yang berkualitas juga mampu memanfaatkan dukungan fasilitas seperti modul, bahan ajar, media belajar yang lengkap, fasilitas laboratorium yang memadai serta melakukan evaluasi yang jelas terkait dengan substansi kompetensi yang diukur, cara evaluasi, serta adanya keadilan dan keterbukaan untuk diketahui siswa. Kondisi seperti ini akan menimbulkan gairah siswa untuk menguasai apa yang telah diajarkan guru, yang untuk selanjutnya akan diujikan atau dievaluasi, sehingga diharapkan dapat meningkatkan prestasi belajarnya. Kualitas Proses Belajar Mengajar di Sekolah Menengah Kejuruan Negeri 1 Surabaya dan Sekolah Menengah Kejuruan Ketintang Surabaya harus ditingkatkan lagi guna menyiapkan lulusan yang lebih baik. Dengan pertimbangan kondisi nyata yang ada di sekolah tersebut, maka dibutuhkan peningkatan kompetensi guru melalui pelatihan penulisan penelitian tindakan kelas supaya kualitas pembelajaran di Sekolah Menengah Kejuruan Negeri 1 Surabaya dan Sekolah Menengah Kejuruan Ketintang Surabaya dapat meningkat.

Menurut Carr dan Kemmis, hakikat penelitian tindakan kelas adalah suatu bentuk penelitian refleksi diri (self reflective) yang dilakukan oleh para partisipan dalam situasi sosial untuk memperbaiki rasionalitas dan kebenaran, yang meliputi: praktik-praktik sosial atau pendidikan yang dilakukan sendiri; pengertian mengenai praktik-praktik tersebut, dan situasi-situasi di mana praktik-praktik tersebut dilaksanakan. Sedangkan McNiff (1992), memandang hakikat penelitian tindakan kelas adalah sebagai bentuk penelitian reflektif yang dilakukan oleh guru sendiri, yang hasilnya dapat dimanfaatkan sebagai alat untuk pengembangan keahlian mengajar. Sementara itu Suharsimi Arikunto (2008) menerangkan pengertian penelitian tindakan kelas, adalah suatu kegiatan mencermati suatu obyek dengan menggunakan cara dan aturan metodologi tertentu untuk memperoleh data atau informasi yang bermanfaat dalam meningkatkan mutu suatu hal yang menarik minat dan penting bagi peneliti.

Dalam peneltian tindakan kelas, guru harus bertindak sebagai pengajar sekaligus peneliti. Fokus penelitian berupa kegiatan pembelajaran. Guru merupakan orang yang paling akrab dengan kelasnya dan biasanya interaksi yang terjadi antara guru dan siswa berlangsung secara unik. Keterlibatan guru dalam berbagai kegiatan inovatif dan kreatif yang bersifat pengembangan mengharuskan guru mampu melakukan peneltian tindakan kelas di kelasnya. Adapun keunggulan penelitian tindakan kelas adalah praktis dan langsung relevan untuk situasi yang aktual; kerangka kejanya teratur; berdasarkan pada observasi nyata dan obyektif; fleksibel dan adaptif; dapat digunakan untuk inovasi pembelajaran; dapat digunakan untuk mengembangkan kurikulum tingkat kelas; dapat digunakan untuk meningkatkan kepekaan atau profesionalisme guru.

\section{METODE}

Kegiatan pengabdian kepada masyarakat dilakukan dengan cara mengadakan workshop. Penelitian Tindakan Kelas di Sekolah Menengah Kejuruan Negeri 1 Surabaya. Adapun runtutan kegiatan pengabdian kepada masyarakat sebagai berikut :

1. Persiapan

a. Sosialisasi Program

Program pengabdian kepada masyarakat disampaikan kepada kepala sekolah SMKN 1 Surabaya dan direspon positif. Selajutnya kegiatan dikoordinasikan oleh kepala sekolah yaitu dengan cara menyampaikan informasi pelaksaan workshop penelitian tindakan kelas kepada guruguru di SMKN 1 Surabaya dan guruguru SMK Ketintang Surabaya.

b. Pendataan Masalah

Masalah-masalah yang muncul didata melalui kepala sekolah SMKN 1 Surabaya dan SMK Ketintang Surabaya.

c. Pendataan Guru Guru yang terdaftar ikut dalam pelatihan berjumlah 21 orang.

2. Pelaksanaan

a. Penyampaian Materi

b. Praktek dan review penelitian tindakan kelas 
c. Analisis dan hasil diskusi

d. Pembimbingan penulisan penelitian tindakan kelas

e. Pembimbingan penulisan artikel jurnal hasil penelitian tindakan kelas

Khalayak sasaran yaitu peserta pengabdian masyarakat adalah guru-guru Sekolah Menengah Kejuruan Negeri 1 Surabaya berjumlah 11 orang dan guru-guru SMK Ketintang Surabaya berjumlah 10 orang dari Bidang Bisnis dan Manajemen. Adapun metode yang digunakan dalam kegiatan ini yaitu :

1. Metode : Workshop

2. Materi Workshop dan Pelatihan

a. Hakekat Penelitian Tindakan Kelas

b. Langkah-langkah Penelitian Tindakan Kelas

c. Pendahuluan

d. Kajian Teori, Konseptual dan Daftar Rujukan

e. Metodologi Penelitian Tindakan Kelas

f. Analisis hasil dan kesimpulan penelitian tindakan kelas

g. Model-model pembelajaran inovatif

h. Pendampingan penulisan naskah artikel hasil penelitian tindakan kelas.

\section{HASIL DAN PEMBAHASAN}

Workshop pelatihan penulisan penelitian tindakan kelas ini dilaksanakan pada hari Jumat dan Sabtu, 04-05 Agustus 2017, dengan susunan acara sebagai berikut:

\section{Workshop Pelatihan Penelitian Tindakan Kelas secara in classrom. \\ Hari pertama pelaksanaan, tim} pengabdian kepada masyarakat membagikan kuisioner kepada peserta untuk mengetahui kemampuan pedagogic guru terkait dengan pembelajaran dan penulisan penelitian tindakan kelas. Guru diharapkan sudah mengembangkan pembelajaran dengan cara melakukan inovasi dan kreatifitas pembelajaran baik yang berkaitan dengan materi ajar, modul, media, metode, model dan evaluasi pembelajaran. Sering kali inovasi pembelajaran tersebut dalam kenyataannya menemui kendala/permasalahan. Kendala/ permasalahan yang di temui guru di dalam kelas dapat menjadi inspirasi dalam membuat judul penelitian tindakan kelas. Untuk mempermudah guru maka tim pengabdian memberikan lampiran draft proposal penelitian tindakan kelas sehingga mempermudah kelompok membuat konsep dasar proposal penelitian tindakan kelas. Adapun respon peserta terhadap kegiatan pelatihan penulisan penelitian tindakan kelas disajikan pada tabel 1 sebagai berikut:

Tabel 1. Presentase Jawaban Responden

\begin{tabular}{clcc}
\hline No & \multicolumn{1}{c}{ Pertanyaan } & $\begin{array}{c}\text { Tingkat } \\
\text { Kesesuaian (\%) }\end{array}$ \\
\hline 1 & $\begin{array}{l}\text { Apakah selama ini sudah melaksanakan inovasi } \\
\text { pembelajaran di dalam proses belajar mengajar di kelas? }\end{array}$ & $70 \%$ \\
\hline 2 & $\begin{array}{l}\text { Permasalahan kegiatan belajar mengajar yang ditemui di } \\
\text { dalam kelas telah digunakan sebagai dasar ide/gagasan } \\
\text { untuk melakukan penelitian tindakan kelas? }\end{array}$ & $55 \%$ \\
\hline 3 & $\begin{array}{l}\text { Dalam melakukan penelitian tindakan kelas sering } \\
\text { berkolabarasi dengan teman sejawat? }\end{array}$ & $85 \%$ \\
\hline
\end{tabular}

Sumber: Data primer diolah

Berdasarkan tabel diatas responden yang menyatakan sudah melaksanakan inovasi pembelajaran di dalam proses belajar mengajar di kelas sebesar $70 \%$. Dalam proses perencanaan penelitian tindakan kelas guru sering menggunakan permasalahan kegiatan belajar mengajar seperti materi ajar, modul, media, metode dan model pembelajaran untuk digunakan sebagai dasar ide/gagasan dalam melakukan penelitian tindakan kelas, jumlahnya sebesar $55 \%$, dan sebesar $85 \%$ responden yang menyatakan bahwa dalam melakukan penelitian tindakan kelas selalu berkolaborasi dengan teman sejawat.

Untuk mempermudah peserta dalam membuat draft proposal penelitian tindakan kelas, tim pengabdian kepada masyarakat menyampaikan terlebih dahulu materi pelatihan meliputi teori-teori penelitian tindakan kelas, tema-tema yang layak untuk diangkat menjadi judul proposal penelitian tindakan kelas, dan teknis penyusunan isi 
proposal penelitian tindakan kelas, serta materi model-model pembebelajaran inovatif. Kemudian tim pengabdian kepada masyarakat membagi peserta yang berjumlah 21 orang menjadi 7 kelompok, setiap kelompok terdiri dari tiga sampai empat orang. Topik dan judul proposal diserahkan kepada masing-masing kelompok pembuat proposal, tim pengabdian kepada masyarakat memberikan masukandan saran seperlunya. Proses pembuatan draft proposal itu sendiri berlangsung selama 2 hari. Setelah selesai membuat cara smart menyusun proposal penelitian tindakan kelas, masing-masing kelompok wajib memaparkan hasilnya dengan cara mempresentasikan di depan peserta lainnya. Tim reviewer akan memberi masukan dan catatan untuk setiap bagian dalam menyusun proposal.

Hasil evaluasi pemaparan dari 7 kelompok dalam mempresentasi smart draft proposal penelitian tindakan kelas dapat dilihat pada grafik dibawah ini:

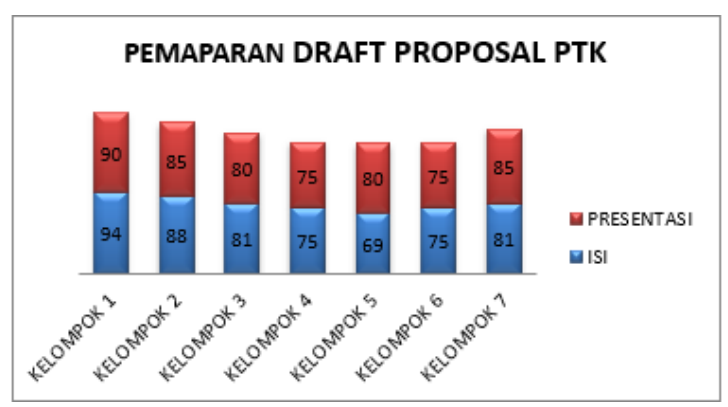

Sumber: Data primer diolah

\section{Praktik Pembuatan Proposal Penelitian Tindakan Kelas Secara Out Class.}

Dalam praktik pembuatan proposal penelitian tindakan kelas secara out class. Setiap kelompok diminta mengirim laporan proposal dalam bentuk hard copy tanpa dijilid ke tim pengabdian kepada masyarakat di Fakultas Ekonomi, setelah itu tim melakukan revisi. Setelah draft proposal direvisi maka oleh tim akan mengembalikan ke sekolah untuk segera ditindak lanjuti oleh masing-masing kelompok, dan segera memperbaikinya. Kemudian guru bisa melaksanakan penelitian tindakan kelas.

\section{Pelatihan dan Pendampingan Penulisan Artikel Hasil Penelitian Tindakan Kelas}

Pelaksanaan kegiatan workshop penulisan artikel pada hari Jum'at dan Sabtu tanggal 13 s.d 14 Oktober bertempat di Sekolah Menengah Kejuruan Negeri 1 Surabaya. Dimana dihadiri kurang lebih hanya 10 guru yaitu 8 dari Sekolah Menengah Kejuruan Negeri 1 Surabaya dan 2 dari Sekolah Menengah Kejuruan Ketintang Surabaya. Perwakilan kelompok yang hadir mengamati pedoman penulisan artikel unesa, kemudian mereka menerapkan pedoman tersebut ke dalam sebuah naskah artikel hasil penelitian tindakan kelas menjadi naskah yang siap untuk dmasukkan jurnal. Hasilnya dari 7 judul penelitian tindakan kelas yang sudah dibuat oleh masing-masing kelompok, tim reviewer menilai ada 5 judul yang layak untuk dibuat menjadi artikel dan bisa di terbitkan di jurnal nasional yang bereputasi. Lebih jelasnya kelima judul artikel dapat dilihat pada tabel 2 di bawah ini :

Tabel 2. Judul Artikel IImiah Hasil PTK

\begin{tabular}{cl}
\hline No & \multicolumn{1}{c}{ Judul PTK } \\
\hline 1 & $\begin{array}{l}\text { Penerapan Metode CIRC (Cooperative Integrated Reading And Composition) } \\
\text { Dalam Meningkatkan Pemahaman Konsep Dan Hasil Belajar Siswa Materi } \\
\text { Mengelola Dana Kas Kecil }\end{array}$ \\
\hline 2 & $\begin{array}{l}\text { Penerapan Model Pembelajaran Murder Untuk Meningkatkan Hasil Belajar Siswa } \\
\text { Materi Dasar-Dasar Komunikasi Kantor }\end{array}$ \\
\hline 3 & $\begin{array}{l}\text { Penerapan Model Pembelajaran Mind Mapping untuk meningkatkan hasil belajar } \\
\text { siswa pada kompetensi keahlian keprotokolan }\end{array}$ \\
\hline 4 & $\begin{array}{l}\text { Penerapan Model Pembelajaran Demonstrasi Untuk Meningkatkan hasil Belajar } \\
\text { Siswa Materi Prosedur Penggunaan Peralatan Kearsipan }\end{array}$
\end{tabular}




\begin{tabular}{cc}
\hline No & \multicolumn{1}{c}{ Judul PTK } \\
\hline 5 & $\begin{array}{l}\text { Peningkatan Keterampilan Mengetik 10 Jari Dengan Metode Drill Melalui Typing } \\
\text { Master Dan Ms. Word Berbantuan Media Job Sheet }\end{array}$
\end{tabular}

\section{PEMBAHASAN}

Tujuan pelatihan penelitian tindakan kelas bagi Guru bidang bisnis manajemen adalah untuk meningkatkan kualitas pembelajaran di Sekolah Menengah Kejuruan dan Ketintang Surabaya.Hal ini sejalan dengan Suharsimi Arikunto (2008) yang menerangkan pengertian penelitian tindakan kelas, sebagai berikut: Penelitian, ini menunjuk pada suatu kegiatan mencermati suatu obyek dengan menggunakan cara dan aturan metodologi tertentu untuk memperoleh data atau informasi yang bermanfaat dalam meningkatkan mutu suatu hal yang menarik minat. Guru merupakan salah satu kunci utama penentu keberhasilan pendidikan, termasuk semua proses di dalamnya. Guru yang berkualitas akan dapat mengajar dengan baik, merencanakan dan menggunakan strategi pembelajaran yang tepat, sehingga siswa akan terfasilitasi untuk belajar dengan mudah dan efektif, yang akhirnya dapat meningkatkan prestasi belajar siswa. Guru yang berkualitas juga mampu memanfaatkan dukungan fasilitas seperti modul, bahan ajar, media belajar yang lengkap, fasilitas laboratorium yang memadai serta melakukan evaluasi yang jelas terkait dengan substansi kompetensi yang diukur, cara evaluasi, serta adanya keadilan dan keterbukaan untuk diketahui siswa.

Manfaat yang dapat dirasakan oleh guru bidang bisnis manajemen adalah pada saat evaluasi hasil pemaparan draft proposal penelitian tindakan kelas ada 2 aspek penilaian yang dapat digunakan untuk menilai hasil pembuatan draft proposal penelitian tindakan kelas yang pertama adalah isi di dalamnya ada 4 indikator yakni: (1) penguasaan materi, (2) Kecocokan antara isi yang dipresentasikan dengan isi proposal,(3) tampilan slide, (4) kemampuan mempertahankan argumen. Yang kedua adalah presentasi didalamnya ada lima indicator yang dijadikan bahan evaluasi yaitu: (1) Kualitas suara (volume, artikulasi suara, intonasi); (2) Pembawaan (cara pandang, gerak tubuh yang efektif, ketenangan); (3) Berpakaian sopan dan rapi; (4) Penggunaan bahasa yang benar ; (5) Tanggap dan siap menerima terhadap masukan. Dalam kegiatan ini banyak sekali diskusi yang terjadi diantara guru maupun tim pengabdian masyarakat, dan diakhir kegiatan diberikan masukan- masukan oleh tim pengabdian masyarakat terkait isi, tata tulis dan sebagainya. Hal tersebut ditunjang oleh pendapat McNiff (1992), memandang hakikat penelitian tindakan kelas adalah sebagai bentuk penelitian reflektif yang dilakukan oleh guru sendiri, yang hasilnya dapat dimanfaatkan sebagai alat untuk pengembangan keahlian mengajar. Program pengembangan keprofesian berkelanjutan merupakan salah satu cara untuk memperkecil jarak antara pengetahuan, keterampilan, kompetensi sosial dan kepribadian yang guru miliki sekarang dengan apa yang menjadi tuntutan ke depan berkaitan dengan profesinya guru. Kegiatan pengembangan keprofesian berkelanjutan dikembangkan atas dasar profil kinerja guru sebagai perwujudan hasil penilaian kinerja guru yang didukung dengan hasil evaluasi diri. Kegiatan pengembangan keprofesian berkelanjutan dapat meningkatkan keprofesian guru guna memenuhi tuntutan masa depan dalam melaksanakan tugas dan kewajibannya sesuai dengan kebutuhan sekolah dalam rangka memberikan layanan pembelajaran yang berkualitas kepada peserta didik. Sesuai dengan amanat Peraturan Menteri Negara Pemberdayaan Aparatur Negara dan Reformasi Birokrasi Nomor 16 Tahun 2009 tentang Jabatan Fungsional Guru dan Angka Kreditnya, pengembangan keprofesian berkelanjutan diakui sebagai salah satu unsure utama selain kegiatan pembelajaran/ pembimbingan dan tugas tambahan lain yang relevan dengan fungsi sekolah/madrasah yang diberikan angka kredit untuk pengembangan karir guru. Penelitian tindakan kelas salah satu bentuk pengembangan tersebut dimana guruguru dapat mempublikasikan hasil penelitian tindakan kelas di jurnal nasional yang bereputasi. Harapannya melalui kegiatan publikasi ilmiah akan terwujud guru profesional yang bukan hanya sekedar memiliki ilmu pengetahuan yang kuat,tuntas dan tidak setengah-setengah, tetapi juga memiliki kepribadian yang matang, kuat dan seimbang. Dengan penguasaan ilmu pengetahuan dan teknologi yang kuat, tuntas dan tidak setengahsetengah serta kepemilikan kepribadian yang 
prima, maka diharapkan guru terampil membangkitkan minat peserta didik kepada ilmu pengetahuan dan teknologi melalui penyajian layanan pendidikan yang bermutu. Mereka mampu membantu dan membimbing peserta didik untuk berkembang dan mengarungi dunia ilmu pengetahuan dan teknologi yang secara cepat berubah sebagai ciri dari masyarakat abad 21 .

\section{SIMPULAN DAN SARAN}

Pelaksanaan pelatihan penelitian tindakan kelas yang dilakukan oleh tim Pengabdian Kepada Masyarakat untuk meningkatkan kualitas pembelajaran di kelas dengan cara meningkatkan kompetensi guru bidang keahlian bisnis manajemen melalui penelitian tindakan kelas di Sekolah Menengah Kejuruan Negeri 1 Surabaya dan Sekolah Menengah Kejuruan Ketintang Surabaya. Dan yang paling utama melakukan pendampingan dalam penulisan artikel ilmiah hasil penelitian tindakan kelas untuk diterbitkan di jurnal nasional yang terakerdiatasi. Umpan balik dari peserta pelatihan adalah perlu tambahan waktu, serta kegiatan pengabdian diadakan secara rutin, sehingga hubungan baik antara sekolah dan perguruan tinggi semakin baik.

Bagi Sekolah Menengah Kejuruan Negeri 1 Surabaya dan Sekolah Menengah Kejuruan Ketintang Surabaya sebaiknya meningkatkan publikasi ilmiah melalui penulisan karya ilmiah yaitu penelitian tindakan kelas sehingga guru selain mengajar juga dapat melakukan penelitian di dalam kelas.

Bagi guru-guru bidang bisnis manajemen lebih kreatif dan inovatif dalam melakukan pembelajaran di dalam kelas sehingga peserta didik tidak mudah bosan dan meningkatkan hasil belajar siswa melalui penelitian tindakan kelas karena praktis dan langsung relevan untuk situasi yang actual.

\section{DAFTAR PUSTAKA}

McNiff, Jean. (1992). Action Research:
Principle and Practice. London:
Routledge.

Suharsimi Arikunto, Suhardjono dan Supardi. (2008). Penelitian Tindakan Kelas. Jakarta: Bumi Aksara. 